\title{
Chromosome Sizes of Phytoplasmas Composing Major Phylogenetic Groups and Subgroups
}

\author{
C. Marcone, H. Neimark, A. Ragozzino, U. Lauer, and E. Seemüller
}

First, fourth, and fifth authors: Biologische Bundesanstalt für Land- und Forstwirtschaft, Institut für Pflanzenschutz im Obstbau, D-69221, Dossenheim, Germany; second author: Department of Microbiology and Immunology, State University of New York, Health State Center at Brooklyn, Brooklyn 11203-2098; and third author: Dipartimento di Arboricoltura, Botanica e Patologia Vegetale, Sez. Patologia Vegetale, Università di Napoli Federico II, I-80055 Portici, Napoli, Italy. Accepted for publication 31 May 1999.

\begin{abstract}
Marcone, C., Neimark, H., Ragozzino, A., Lauer, U., and Seemüller, E. 1999. Chromosome sizes of phytoplasmas composing major phylogenetic groups and subgroups. Phytopathology 89:805-810.

Chromosome sizes of 71 phytoplasmas belonging to 12 major phylogenetic groups including several of the aster yellows subgroups were estimated from electrophoretic mobilities of full-length chromosomes in pulsed-field gels. Considerable variation in genome size, from 660 to 1,130 kilobases (kb), was observed among aster yellows phytoplasmas. Chromosome size heterogeneity was also observed in the stolbur phytoplasma group (range 860 to $1,350 \mathrm{~kb}$ ); in this group, isolate STOLF contains the largest chromosome found in a phytoplasma to date. A wide range of chromosome sizes, from 670 to $1,075 \mathrm{~kb}$, was also identified in the X-disease group. The other phytoplasmas examined, which included

members of the apple proliferation, Italian alfalfa witches' broom, faba bean phyllody, pigeon pea witches' broom, sugarcane white leaf, Bermuda grass white leaf, ash yellows, clover proliferation, and elm yellows groups, all have chromosomes smaller than 1 megabase, and the size ranges within each of these groups is narrower than in the aster yellows, stolbur, and $\mathrm{X}$-disease groups. The smallest chromosome, $\approx 530 \mathrm{~kb}$, was found in two Bermuda grass white leaf phytoplasma isolates. This not only is the smallest mollicute chromosome found to date, but also is the smallest chromosome known for any cell. More than one large DNA band was observed in several phytoplasma preparations. Possible explanations for the occurrence of more than one band may be infection of the host plant by different phytoplasmas, the presence of more than one chromosome in the same organism, or the presence of large extrachromosomal DNA elements.
\end{abstract}

Phytoplasmas are wall-less, uncultivated procaryotes in the class Mollicutes (trivial name mycoplasmas) that are associated with diseases of several hundred plant species $(26,35)$. Sequence analysis of $16 \mathrm{~S}$ ribosomal DNA (rDNA) and ribosomal protein genes showed that phytoplasmas compose a discrete monophyletic clade that is more closely related to acholeplasmas than to other mollicutes $(13,36)$. The closest identified relatives of the phytoplasmas are Acholeplasma palmae and A. modicum (19) in the anaeroplasma clade defined by Weisburg et al. (39). According to phylogenetic data based on $16 \mathrm{~S}$ rDNA sequences, about 20 subclades (groups) can currently be distinguished within the phytoplasma clade (35). Phytoplasma subclades are considered to represent the equivalent of distinct species under the provisional taxonomic species status candidatus (15). Within most subclades, further differentiation is possible by restriction fragment length polymorphism (RFLP) analysis or other methods. On the basis of RFLP analysis of polymerase chain reaction (PCR)-amplified 16S rDNA and ribosomal protein genes, the aster yellows (AY) group, currently the largest phytoplasma subclade, was divided into several subgroups (19).

Another important characteristic of these uncultivated plant pathogens is their genome size. For the culturable mollicutes, a wealth of data on this property is available. The genome sizes of culturable mollicutes range from more than 2,200 to less than 600 kilobases $(\mathrm{kb})$, with overlapping values between the various mollicute genera. A particularly wide range has been observed among Myco-

Corresponding author: C. Marcone

E-mail address: carmine.marcone@urz.uni-heidelberg.de

Publication no. P-1999-0719-02R

(C) 1999 The American Phytopathological Society plasma spp., whose genome sizes range from 1,380 down to $580 \mathrm{~kb}$, and Spiroplasma spp., which have an even greater span, from 2,220 to $780 \mathrm{~kb}$. In the genus Acholeplasma, the size range is narrower, varying between 1,500 and $1,650 \mathrm{~kb}$ (30). Information on genome sizes of phytoplasmas is currently available for only 12 strains, mainly from the AY and X-disease groups, and these have chromosome sizes between 1,185 and $600 \mathrm{~kb}(12,29,40)$. The purpose of the work reported here was to expand our knowledge of the range of genome sizes within the phytoplasma clade and to ascertain whether chromosome sizes among these groups cluster or differ in range in any characteristic manner. For this purpose, we examined representative strains from a number of major taxonomic groups and subgroups as defined by Seemüller et al. (35) and Lee et al. (19).

\section{MATERIALS AND METHODS}

Sources of phytoplasmas. The phytoplasmas examined are listed in Table 1. Most isolates were previously transmitted to periwinkle (Catharanthus roseus (L.) G. Don) and maintained in this host by periodic grafting in an insect-proof greenhouse. In addition, the following naturally infected plants were sampled in the field in the Campania region of southern Italy: two celery plants (isolates CeY1 and 2) from the same field, two patches of Bermuda grass (BGWL1 and 2) from different locations, and two plants of Picris echioides L. (bristly oxtongue; isolates PEP and PEY).

Pulsed-field gel electrophoresis (PFGE) analysis. Leaf midribs were taken for phytoplasma extraction. Samples were prepared and PFGE was carried out as described by Neimark and Kirkpatrick (29), except that the lysis solution was changed several times, SeaPlaque agarose (FMC BioProducts, Rockland, ME) was used, and the blocks were not gamma-irradiated. The PFGE was carried out in a CHEF DRIII apparatus (Bio-Rad Laboratories, Rich- 
TABLE 1. Genome size of phytoplasmas of various taxonomic groups and subgroups

\begin{tabular}{|c|c|c|c|c|}
\hline Phytoplasma (geographic origin) & Strain/isolate & Taxonomic group/subgroup ${ }^{a}$ & Reference/further information & Genome size $(\mathrm{kb})$ \\
\hline Chrysanthemum yellows (Germany) & CHRYM & Aster yellows/A & Obtained from R. Marwitz & 780 \\
\hline Cuscuta odorata latent (Germany) & COL & Aster yellows/A & 31 & 780 \\
\hline Plantago virescence (Germany) & PVM & Aster yellows/A & 31 & 810 \\
\hline American aster yellows (United States) & AAY & Aster yellows/B & 35 & $915^{\mathrm{b}}$ \\
\hline Cactus virescence (probably United States) & $\mathrm{CC}$ & Aster yellows/B & 35 & $935^{\mathrm{b}}$ \\
\hline Catharanthus virescence (Peru) & CVL & Aster yellows/B & 31 & 680 \\
\hline Delphinium virescence (Germany) & DEV & Aster yellows/B & 31 & 800 \\
\hline Diplotaxis virescence (Spain) & DIV & Aster yellows/B & 31 & 1,000 \\
\hline Eastern American aster yellows (United States) & AYW & Aster yellows/B & 31 & 1,040 \\
\hline French Aster yellows (France) & AYM1 & Aster yellows/B & Obtained from G. Morvan & $1,120^{\mathrm{b}}$ \\
\hline Gladiolus witches' broom (France) & GLAWC & Aster yellows/B & 1 & $1,080,790^{\mathrm{b}}$ \\
\hline Hydrangea phyllody (Belgium) & HYDB & Aster yellows/B & 31 & 660 \\
\hline Hydrangea phyllody (France) & HYDF & Aster yellows/B & 7 & 800 \\
\hline Plantago virescence (Germany) & PVW & Aster yellows/B & 31 & 910 \\
\hline Rape virescence & RV & Aster yellows/B & 31 & 1,130 \\
\hline Safflower phyllody (Israel) & SAFP & Aster yellows/B & 31 & 740 \\
\hline Sandal spike (India) & SAS & Aster yellows/B & 31 & 690 \\
\hline Clover phyllody (Germany) & KVG & Aster yellows/C & 34 & 830 \\
\hline Clover phyllody (France) & KVF & Aster yellows/C & 8 & 750 \\
\hline From grapevine (Germany) & GY & Aster yellows/C & 21 & 830 \\
\hline Leafhopper-borne (Germany) & CVA & Aster yellows/C & 31 & 880 \\
\hline Potato purple top (France) & PPT & Aster yellows/C & 5 & 758 \\
\hline From apricot (Spain) & AYA & Aster yellows/F & 35 & $740^{\mathrm{c}}$ \\
\hline Leafhopper-borne (Germany) & CVB & Aster yellows/F & 31 & 910,680 \\
\hline Aster yellows (Germany) & AV976 & Aster yellows/L & Obtained from R. Marwitz & $1,095,790$ \\
\hline Aster yellows (Germany) & AV2192 & Aster yellows/L & 31 & 1,125 \\
\hline From Bermuda grass (Thailand) & AYBG & Aster yellows/L & 31 & 780 \\
\hline Primula yellows (Germany) & PRIVA & Aster yellows/L & 31 & $830^{\mathrm{b}}$ \\
\hline Aster yellows (Germany) & AVUT & Aster yellows/M & Obtained from R. Marwitz & $910^{\mathrm{b}}$ \\
\hline Celery yellows (Italy) & CeY1 & Stolbur & C. Marcone, unpublished data & 980 \\
\hline Celery yellows (Italy) & $\mathrm{CeY} 2$ & Stolbur & C. Marcone, unpublished data & 980 \\
\hline Lavender decline (France) & DEPL & Stolbur & 6 & 990 \\
\hline Grapevine yellows (Italy) & CA-1 & Stolbur & 24 & 1,070 \\
\hline Grapevine yellows (Italy) & $\mathrm{CH}-1$ & Stolbur & 24 & 945 \\
\hline Grapevine yellows (Italy) & SA-1 & Stolbur & 24 & 1,020 \\
\hline Grapevine yellows (Italy) & SA-2 & Stolbur & 24 & 1,080 \\
\hline Grapevine yellows (Germany) & GGY1 & Stolbur & 24 & 860 \\
\hline From sour cherry (France) & MOL & Stolbur & 31 & 1,220 \\
\hline Stolbur of pepper (Serbia) & STOL & Stolbur & 35 & 900 \\
\hline Tomato stolbur (France) & STOLF & Stolbur & 31 & 1,350 \\
\hline Apple proliferation (Germany) & $\mathrm{AT}$ & Apple proliferation & 31 & 645 \\
\hline Apple proliferation (Italy) & AP15 & Apple proliferation & 31 & 690 \\
\hline European stone fruit yellows (Germany) & GSFY1 & Apple proliferation & 23 & 630 \\
\hline European stone fruit yellows (Germany) & GSFY2 & Apple proliferation & 23 & 630 \\
\hline European stone fruit yellows (Italy) & ESFY1 & Apple proliferation & 20 & 630 \\
\hline Pear decline (Germany) & PD1 & Apple proliferation & 23 & 660 \\
\hline From grapevine (Italy) & FDI & $\mathrm{X}$-disease & 31 & 705 \\
\hline Vaccinium witches' broom (Germany) & VAC & $\mathrm{X}$-disease & 31 & 1,075 \\
\hline Western X-disease (United States) & GVX & $\mathrm{X}$-disease & 31 & 670 \\
\hline Western X-disease (United States) & PYLR & $\mathrm{X}$-disease & 31 & 670 \\
\hline Picris echioides phyllody (Italy) & PEP & Italian alfalfa witches' broom & 35 & 605 \\
\hline Cleome phyllody (Thailand) & CLP & Faba bean phyllody & 35 & 720 \\
\hline Cotton phyllody (Burkina Faso) & $\mathrm{CoP}$ & Faba bean phyllody & 35 & 790 \\
\hline Crotalaria saltiana phyllody (Sudan) & CSP & Faba bean phyllody & 35 & 660 \\
\hline Faba bean phyllody (Sudan) & FBP & Faba bean phyllody & 32 & 660 \\
\hline Sesame phyllody (Thailand) & SEPN & Faba bean phyllody & 32 & $660^{\mathrm{b}}$ \\
\hline Sesame phyllody (Thailand) & SEPT & Faba bean phyllody & 32 & 700 \\
\hline Soybean phyllody (Thailand) & SoyP & Faba bean phyllody & 32 & 735 \\
\hline Sunn hemp witches' broom (Thailand) & SUNHP & Faba bean phyllody & 32 & 680 \\
\hline Sunn hemp phyllody (Thailand) & CROP & Faba bean phyllody & 35 & 670 \\
\hline Tomato big bud (Australia) & TBB & Faba bean phyllody & 35 & 690 \\
\hline Picris echioides yellows (Italy) & PEY & Pigeon pea witches' broom & 35 & $740^{\mathrm{b}}$ \\
\hline Leafhopper-borne (Germany) & BVK & Sugarcane white leaf & 35 & 700 \\
\hline Bermuda grass white leaf (Italy) & BGWL1 & Bermuda grass white leaf & 25 & 530 \\
\hline Bermuda grass white leaf (Italy) & BGWL2 & Bermuda grass white leaf & 25 & 530 \\
\hline Ash yellows (United States) & ASHY1 & Ash yellows & 35 & 620 \\
\hline Beet leafhopper-transmitted virescence agent (United States) & BLTVA & Clover proliferation & 35 & 675 \\
\hline Alder yellows (Italy) & ALY & Elm yellows & 35 & 750 \\
\hline Elm yellows (United States) & $\mathrm{EY}$ & Elm yellows & 31 & 730 \\
\hline Elm yellows (France) & ULW & Elm yellows & 35 & 680 \\
\hline Rubus stunt (Italy) & $\mathrm{RuS}$ & Elm yellows & 35 & 820 \\
\hline
\end{tabular}

${ }^{a}$ Group designation proposed by Seemüller et al. (35); AY subgroup designation according to Lee et al. (19) and C. Marcone (unpublished data).

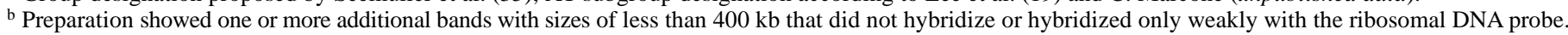

c Two additional bands of approximately 490 and $300 \mathrm{~kb}$ hybridized with a ribosomal DNA probe. 
mond, CA) employing the following protocol: temperature, $14^{\circ} \mathrm{C}$; voltage, $6 \mathrm{~V} / \mathrm{cm}$; pulse parameters, 20 to $120 \mathrm{~s}$; running time, $21 \mathrm{~h}$; angle, $120^{\circ}$; agarose, $1 \%$; and buffer, $0.5 \times$ Tris-borate-EDTA. Size markers were Hansenula wingei chromosomes (Bio-Rad Laboratories), Saccharomyces cerevisiae chromosomes (Bio-Rad Laboratories and Pharmacia Biotechnology, Inc., Uppsala, Sweden), and concatameric lambda DNA ladder (Bio-Rad Laboratories). All preparations were examined by PFGE at least twice. Chromosomal DNA of each phytoplasma was blotted onto nylon membrane as described by Neimark and Kirkpatrick (29) and hybridized as described by Hoheisel et al. (14) with a rDNA probe prepared from phytoplasma strain AAY by PCR amplification using primer pair P1/P7 (37). This probe encompasses the entire 16S rRNA gene, the $16 \mathrm{~S} / 23 \mathrm{~S}$ rDNA spacer region, and the $5^{\prime}$ region of the $23 \mathrm{~S}$ rRNA gene. The probe was purified by extracting the PCRamplified DNA band from agarose using the JETsorb gel extraction kit (GenoMed, Bad Oynhausen, Germany) and labeling with ${ }^{32} \mathrm{P}-\mathrm{dATP}$ using the Prime-It II kit (Stratagene Inc., La Jolla, CA).

\section{RESULTS AND DISCUSSION}

Effect of strains and plant sources on chromosome isolation. A total of about 100 phytoplasma strains obtained mainly from the collection of the Dossenheim Institute was examined. In preparations from 71 phytoplasmas belonging to 12 of the 20 taxonomic groups proposed by Seemüller et al. (35), at least one discrete fulllength phytoplasma chromosome band was obtained (Table 1). These full-length chromosome bands were obtained without utilizing gamma irradiation, presumably by using physical shearing, endogenous nuclease activity, or both during preparation to obtain linearized chromosomes. Previously, where ample amounts of material were available, we used shearing and endogenous nuclease activity instead of gamma irradiation to introduce single doublestrand breaks into chromosomes, but we were cautious in recommending this procedure for precious or irreplaceable samples (4). The large amounts of fragmented DNA visible in the lower portion of the lanes is a reflection of this procedure (Figs. 1 and 2). The best results usually were obtained when plants were fully symptomatic but did not yet show signs of decline. Preparations from $\approx 30$ isolates did not yield any bands or the bands observed were not reproducible, in spite of the fact that samples were taken at different stages of disease development. No relationship was observed between isolates that failed to produce bands and their group affiliation. The failure to demonstrate chromosome bands in these phytoplasma preparations may have been because these isolates did not reach sufficiently high titers in periwinkle. Firrao et al.

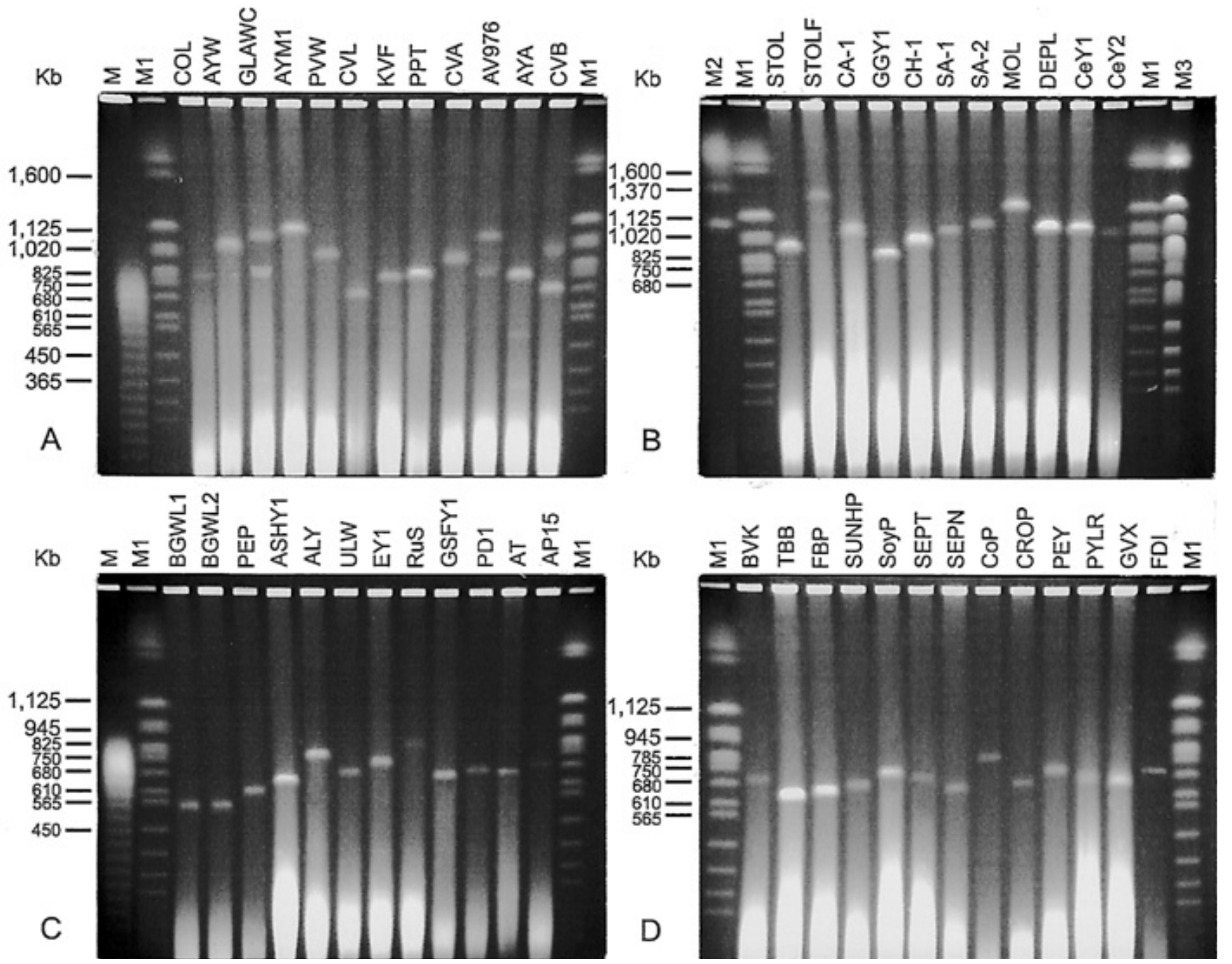

Fig. 1. Full-length phytoplasma chromosomes isolated by pulsed-field gel electrophoresis. The size markers were M, concatameric lambda DNA ladder; M1, Saccharomyces cerevisiae chromosomes; M2, Hansenula wingei chromosomes; and M3, S. cerevisiae chromosomes. A, COL through CVB, aster yellows strains. B, STOL through CeY2, stolbur strains. C, BGWL1 and 2, Bermuda grass white leaf; PEP, Picris echioides phyllody; ASHY1, ash yellows; ALY, alder yellows; ULW and EY1, elm yellows; RuS, rubus stunt; GSFY1, European stone fruit yellows; PD1, pear decline; and AT and AP15, apple proliferation. D, BVK, leafhopper-borne; TBB, tomato big bud; FBP, faba bean phyllody; SUNHP, sunn hemp witches' broom; SoyP, soybean phyllody; SEPT and SEPN, sesame phyllody; CoP, cotton phyllody; CROP, sunn hemp phyllody; PEY, Picris echioides yellows; PYLR and GVX, western X-disease; and FDI, from grapevine. 
(10) obtained much stronger chromosomal DNA bands of the western X-disease phytoplasma following extraction from diseased celery than from diseased periwinkle. In our work, celery also proved to be an excellent phytoplasma host.

AY group. Of the isolates examined, 28 were AY group members belonging to subgroups $\mathrm{A}, \mathrm{B}, \mathrm{C}$, and $\mathrm{F}$, as proposed by Lee et al. (19) or to subgroups L and M, recently identified on the basis of RFLP analysis of PCR-amplified rRNA and tuf gene DNA (C. Marcone, unpublished data) (Table 1; Figs. 1A and 2A). Within subgroup B, the largest subdivision of the AY group (35), genome sizes are quite heterogeneous and range from $1,130 \mathrm{~kb}$ (isolate $\mathrm{RV}$ ) down to $660 \mathrm{~kb}$ (isolate HYDB). Subgroup L, although it currently contains only four isolates, was heterogeneous in chromosome size (range from 1,095 to $780 \mathrm{~kb}$ ). Subgroups $\mathrm{C}$ may be composed of isolates with a relatively narrow size range (880 to $750 \mathrm{~kb}$ ), but, in contrast to chromosome size heterogeneity, a narrow size range cannot be given much weight as a property of a subgroup until several subgroup members have been examined. Obviously, too few members of subgroups A, F, and M have been examined to estimate their subgroup properties. The AY phytoplasmas examined differ greatly in virulence for periwinkle and cause a wide variety of symptoms in this host including virescence, phyllody, small and faintly colored flowers, flower mal- formations, shortening of internodes, elongation and etiolation of internodes, small and deformed leaves, yellowing, and decline. However, we did not observe any relation between symptoms or virulence and genome size among AY isolates.

Previously, Neimark and Kirkpatrick (29) examined 11 phytoplasmas including eight virescence agents (seven AY strains with chromosome sizes between 1,185 and $850 \mathrm{~kb}$ and strain BLTVA with a size of $675 \mathrm{~kb}$ ). These authors found polymorphism in genome sizes among these "virescence phytoplasmas" and noted a difference in size between them and the small genomes of three Xdisease phytoplasmas associated with decline diseases of woody plants ("decline phytoplasmas"). Our results show that chromosome sizes below $850 \mathrm{~kb}$ are common among AY phytoplasmas (Table 1), and these genome sizes overlap those of the so-called decline phytoplasmas. Even AY isolates with chromosome sizes smaller than $700 \mathrm{~kb}$ including CVL, HYDB, and SAS cause virescence and phyllody in periwinkle.

Stolbur group. The stolbur group is composed of isolates with chromosomes mainly at the upper end of the size range and, up to now, no isolate has a chromosome smaller than $860 \mathrm{~kb}$; thus, stolbur isolate chromosomes, on average, are somewhat larger than those of AY isolates and definitely larger than those of any other currently constituted group (Table 1; Figs. 1B and 2B). The group

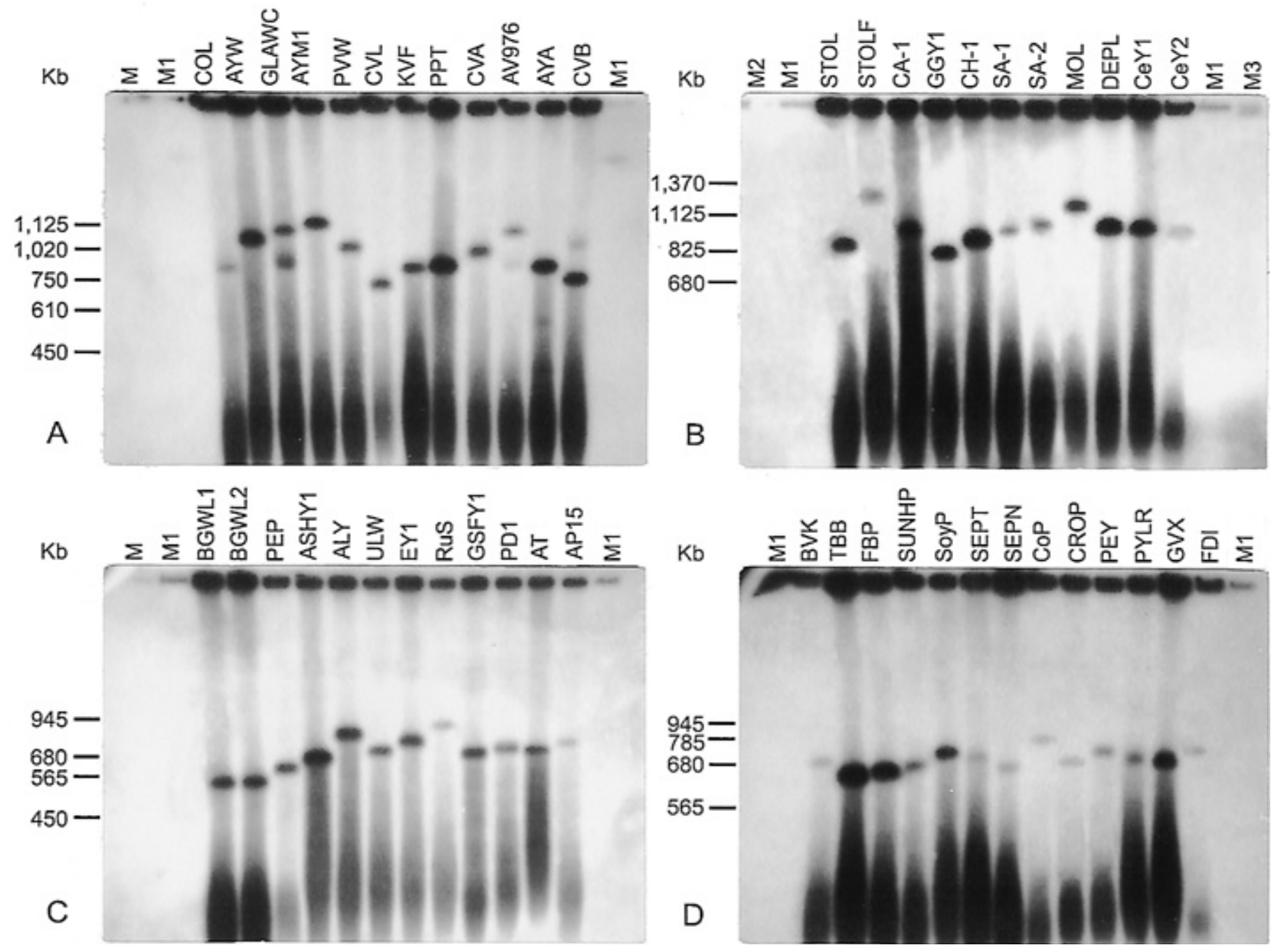

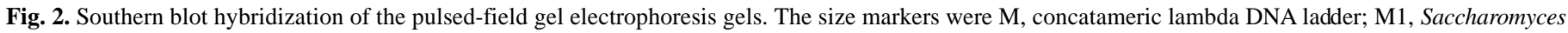

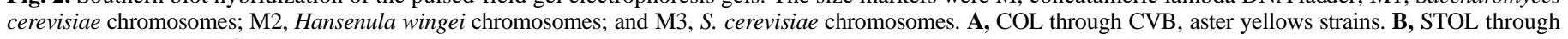

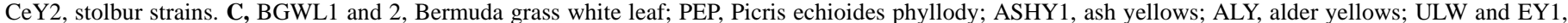

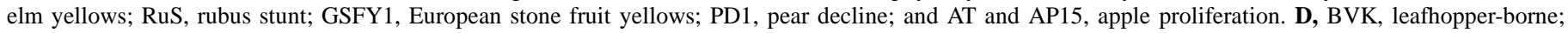

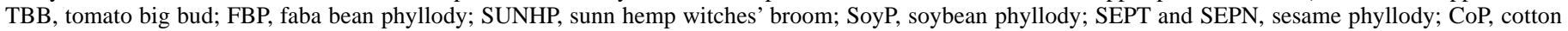
phyllody; CROP, sunn hemp phyllody; PEY, Picris echioides yellows; PYLR and GVX, western X-disease; and FDI, from grapevine. 
includes isolate STOLF, which contains the largest phytoplasma chromosome identified so far, exceeding the largest phytoplasma chromosomes found previously (29) by $155 \mathrm{~kb}$. While the genome sizes of the two celery yellows isolates were identical, the sizes of the grapevine isolates, which are all from the same geographic area of Italy, were all different. It is interesting to note that the two isolates with the largest genomes, MOL and STOLF, were much less virulent for periwinkle than the other stolbur isolates.

$\mathrm{X}$-disease group. In the $\mathrm{X}$-disease group, the genome size of strains GVX and PYLR of the X-disease phytoplasma (Table 1) is identical to that of the western X-disease strain used for chromosome mapping by Firrao et al. (10). Similarly, genome sizes of two other X-disease group members, the phytoplasmas causing peach rosette and Italian clover phyllody, 670 and $630 \mathrm{~kb}$, respectively (9), are within the same range. However, a considerably larger chromosome of approximately $1,075 \mathrm{~kb}$ was identified in strain VAC. This size confirms the value previously obtained by B. Schneider and E. Seemüller (unpublished data) but is larger than that reported by Firrao et al. (9).

Other phytoplasma groups. All the examined members of the remaining 10 phytoplasma groups have genome sizes of less than 1 megabase (Table 1; Figs. $1 \mathrm{C}$ and D and $2 \mathrm{C}$ and D). Size variation within these groups is less than within the AY, stolbur, and X-disease groups. A particularly narrow size range of from 690 to $645 \mathrm{~kb}$ was observed among the apple proliferation (AP) group agents; in this group, all the European stone fruit yellows isolates have the same genome size, whereas the genome sizes of the two isolates from apple that were examined are different (Fig. 1C). Genome sizes of the faba bean phyllody group isolates examined are between 790 and $660 \mathrm{~kb}$ (Table 1). Group member of the species candidatus, Phytoplasma aurantifolia is in the same range (40), whereas the chromosome size of the sweet potato little leaf phytoplasma was estimated to be only $600 \mathrm{~kb}$ (12). Until this study, the sweet potato little leaf phytoplasma was the smallest known phytoplasma genome.

Two samples from Bermuda grass infected with the Bermuda grass white leaf phytoplasma yielded a similar-sized band of approximately $530 \mathrm{~kb}$ (Table 1; Figs. 1C and 2C). These bands hybridized strongly with the rDNA probe, and no other bands were observed; therefore, there is no doubt that the $530-\mathrm{kb}$ band represents the linearized chromosomes of these isolates. Hence, the chromosome of the Bermuda grass white leaf agent is not only the smallest phytoplasma genome but also appears to be the smallest genome known for any self-replicating organism. Previously, the 580-kb chromosome of Mycoplasma genitalium was considered the smallest genome (11). These values are near the calculated $562-\mathrm{kb}$ upper size for a minimal self-sufficient organism (16), while theoretical estimates for a minimal gene complement are considerably lower $(16,22,28)$.

Multiple banding patterns. In preparations from AY isolates GLAWC, CVB, and AV976, we detected two DNA bands that, from their size and their hybridization to the rDNA probe, appear to be full-length phytoplasma chromosomes (Table 1; Figs. 1A and 2A). Similar observations were made by Neimark and Kirkpatrick (29) in analyzing samples from other AY phytoplasma-infected plants. The simplest explanation for the occurrence of two bands is that the plants from which the samples were prepared were infected with two distinct phytoplasmas containing different-sized chromosomes. Apparent multiple phytoplasma infections in a single plant have also been identified by RFLP analysis of PCR-amplified ribosomal DNA by Lee et al. $(17,18)$ and Berges et al. (3). Their effect on virulence and symptomatology is not clear.

More difficult to explain are three bands observed in strain AYA that showed, in addition to a $740-\mathrm{kb}$ band presumed to be the main chromosome, two other bands with estimated sizes of 490 and $300 \mathrm{~kb}$ (Figs. 1A and 2A). Since both smaller bands hybridized with the rDNA probe, it is unlikely that they are plasmids because, to our knowledge, no plasmid has been described that carries a rRNA cistron. Similar-sized bands observed previously in other AY phyto- plasma preparations did not hybridize with rRNA gene probes and were considered to be extrachromosomal replicons or "megaplasmids" (29). Possibly, either of the smaller AYA bands could represent a second smaller AYA chromosome. Two chromosomes are known to occur in the prokaryotes Brucella melitensis (27), Leptospira interrogans (41), and Rhodobacter sphaeroides (38). Agrobacterium tumefaciens $\mathrm{C} 58$ has one circular chromosome plus a linear chromosome (2). Also, the two smaller bands are in the range proposed for the minimal genome size required for life of 318 to $562 \mathrm{~kb}$ (16); $318 \mathrm{~kb}$ corresponds closely to the size for a set of 256 genes proposed by Mushegian and Koonin (28) to be necessary to sustain a cell. Thus, an additional possibility is that one or more minimal chromosomes from another organism may be present in these preparations. These various possibilities can be examined experimentally by using specific probes for ribosomal protein (13), tuf (33), and other conserved genes.

In preparations from several isolates, especially AY group phytoplasmas, we observed one or several bands with sizes mostly between 400 and $50 \mathrm{~kb}$ that did not hybridize or hybridized only weakly with the rDNA probe (Table 1). Large DNA bands that did not hybridize with a $16 \mathrm{~S}$ rDNA probe have also been reported to occur in other AY phytoplasmas; however, these bands did hybridize with a cloned chromosomal fragment from severe aster yellows (29). When we examined different DNA preparations from plants infected with the same strains, these bands were quite variable in different preparations with respect to size and occurrence.

Concluding remarks. The values reported here extend the known range of phytoplasma chromosome sizes to 1,350 to $530 \mathrm{~kb}$ and nearly fill in much of a continuous span. The width of this span is more than twofold in extent and shows that phytoplasma chromosomes have a size range essentially as broad as that of the genus Mycoplasma, the genus with the largest number of species. However, the species composing the genus Mycoplasma appear to be much more diverse than the organisms in the species candidatus genus Phytoplasma, and while the genus Mycoplasma contains more than 100 species (30), currently there are only about 20 taxonomic groups within the phytoplasmas that can be distinguished at the putative species level (35). Also, species in the genus Mycoplasma differ in their 16S rDNA sequences by as much as $25.5 \%$ (40), whereas the maximum $16 \mathrm{~S}$ rDNA sequence dissimilarity within the phytoplasmas is $14 \%$ (35).

Genome sizes among the phytoplasma groups vary. Although these groups may undergo further refinement and subdivision, the varying sizes indicate that different amounts of genomic material have been lost by the phytoplasmas composing the various phylogenetic groups. Accordingly, it should be recognized that an isolate containing a distinctly smaller chromosome may be discovered in any group, because mycoplasma chromosome sizes result from differential losses of genomic material. The small genomes observed in several phytoplasma groups, such as the similar-sized small chromosomes observed in the genus Mycoplasma, probably have evolved to near the minimum size limit. In the case of phytoplasmas, survival requires a genome that permits both insect transmission and ability to grow in a plant.

To date, all attempts by investigators to culture phytoplasmas have failed. The genome sizes of many phytoplasmas are larger than those of many culturable mycoplasmas; therefore, small genome size alone cannot explain the inability to culture phytoplasmas. Although genes required for axenic growth may be disabled or absent from either large or small chromosomes, phytoplasmas possessing larger chromosomes may be more likely to have retained a complement of the genes necessary for independent growth. Thus, phytoplasmas containing large genomes should be included in future cultivation studies (29).

\section{ACKNOWLEDGMENTS}

Work was supported by a grant from the Commission of the European Communities to C. Marcone (Research Training Grant FAIR-BM- 
974428). We thank L. Carraro, M. F. Clark, M.-T. Cousin, R. Credi, F. Dosba, B. C. Kirkpatrick, and R. Marwitz for providing phytoplasma strains; and B. Schneider for providing preliminary data obtained in previous work on phytoplasma genome sizes.

\section{LITERATURE CITED}

1. Albouy, J. 1966. Le problème des germes fins du gladieul. Ann. Epiphyt. (Paris) 17:81-93.

2. Allardet-Servant, A., Michaux-Charachon, S., Jumas-Bilak, E., Karayan, L., and Ramuz, M. 1993. Presence of one linear and one circular chromosome in the Agrobacterium tumefeciens C58 genome. J. Bacteriol. 175: 7869-7874.

3. Berges, R., Cousin, M.-T., Roux, J., Mäurer, R., and Seemüller, E. 1997. Detection of phytoplasma infections in declining Populus nigra 'Italica' trees and molecular differentiation of the aster yellows phytoplasmas identified in various Populus species. Eur. J. For. Pathol. 27:33-43.

4. Carle, P., and Neimark, H. 1995. Mollicute chromosome size determination and characterization of chromosomes from uncultured mollicutes. Pages 119-131 in: Molecular and Diagnostic Procedures in Mycoplasmology (Vol. I). S. Razin and J. G. Tully, eds. Academic Press, San Diego, CA.

5. Cousin, M.-T. 1975. L'enroulement violacé de la pomme de terre. Ann. Phytopathol. 7:167-173.

6. Cousin, M.-T., Moreau, J.-P., Staron, T., and Faivre-Amiot, A. 1970. Le déperissement jaune du lavandin, nouvelle maladie à mycoplasmes. Ann. Phytopathol. 2:227-237.

7. Cousin, M.-T., Sharma, J., Rousseau, J., Poitevin, J.-P., and Savoure, A. 1986. Hydrangea virescence. I. Description of the disease and its transmission to the differential host plant Catharanthus roseus by Cuscuta subinclusa. Agronomie 6:249-254.

8. Faivre-Amiot, A., Moreau, J.-P., Cousin, M.-T., and Staron, T. 1970. Essai de mise en culture de l'agent de la phyllodie du trèfle. Ann. Phytopathol. 2:251-258.

9. Firrao, G., Scott, S. W., Smart, C. D., Carraro, L., Chang, C. J., Seemüller, E., and Kirkpatrick, B. C. 1996. Serological and molecular genetic characterization of five members of the X-disease phytoplasma clade. IOM (Int. Organ. Mycoplasmol.) Lett. 4:278-279.

10. Firrao, G., Smart, C. D., and Kirkpatrick, B. C. 1996. Physical map of the western X disease phytoplasma chromosome. J. Bacteriol. 178:3985-3988.

11. Fraser, C. M., Gocayne, J. D., White, O., Adams, M. D., Clayton, R. A., Fleischmann, R. D., Bult, C. J., Kerlavage, A. R., Sutton, G., Kelley, J. M., Fritchman, J. D., Weidman, J. F., Small, K. V., Sandusky, M., Fuhrmann, J., Nguyen, D., Utterback, T. R., Saudek, D. M., Phillips, C. A., Merrick, J. M., Tomb, J.-F., Dougherty, B. A., Bott, K. F., Hu, P.-C., Lucier, T. S., Peterson, S. N., Smith, H. O., Hutchison III, C. A., and Venter, J. C. 1995. The minimal gene complement of Mycoplasma genitalium. Science 270: 397-403.

12. Gibb, K. S., Padovan, A. C., and Mogen, B. D. 1995. Studies on sweet potato little-leaf phytoplasma detected in sweet potato and other plant species growing in northern Australia. Phytopathology 85:169-174.

13. Gundersen, D. E., Lee, I.-M., Rehner, S. A., Davis, R. E., and Kingsbury, D. T. 1994. Phylogeny of mycoplasmalike organisms (phytoplasmas): A basis for their classification. J. Bacteriol. 176:5244-5254

14. Hoheisel, J. D., Lennon, G. G., Zehetner, G., and Lehrach, H. 1991. Use of high coverage reference libraries of Drosophila melanogaster for relational data analysis; a step towards mapping and sequencing of the genome. J. Mol. Biol. 220:903-914.

15. International Committee on Systematic Bacteriology. Subcommittee on the Taxonomy of Mollicutes. 1997. Minutes of the interim meetings, 12 and 18 July 1996, Orlando, Florida, USA. Int. J. Syst. Bacteriol. 47:911-914.

16. Itaya, M. 1995. An estimation of minimal genome size required for life. FEBS (Fed. Eur. Biochem. Soc.) Lett. 362:257-260.

17. Lee, I.-M., Bertaccini, A., Vibio, M., and Gundersen, D. E. 1995. Detection of multiple phytoplasmas in perennial fruit trees with decline symptoms in Italy. Phytopathology 85:728-735.

18. Lee, I.-M., Gundersen, D. E., Hammond, R. W., and Davis, R. E. 1994. Use of mycoplasmalike organism (MLO) group-specific oligonucleotide primers for nested-PCR assays to detect mixed-MLO infections in a single host plant. Phytopathology 84:559-566.

19. Lee, I.-M., Gundersen-Rindal, D. E., Davis, R. E., and Bartoszyk, I. M. 1998. Revised classification scheme of phytoplasmas based on RFLP analysis of $16 \mathrm{~S}$ rRNA and ribosomal protein gene sequences. Int. J. Syst. Bacteriol. 48:1153-1169.

20. Loi, N., Carraro, L., Musetti, R., Pertot, I., and Osler, R. 1995. Dodder transmission of two different MLOs from plum trees affected by "leptonecrosis". Acta Hortic. 386:465-470.
21. Maixner, M., Ahrens, U., and Seemüller, E. 1994. Detection of mycoplasmalike organisms associated with a yellows disease of grapevine in Germany. J. Phytopathol. 142:1-10.

22. Maniloff, J. 1996. The minimal cell genome: "On being the right size." Proc. Natl. Acad. Sci. U.S.A. 93:10004-10006.

23. Marcone, C., Hergenhahn, F., Ragozzino, A., and Seemüller, E. 1999. Dodder transmission of pear decline, European stone fruit yellows, rubus stunt, Picris echioides yellows and cotton phyllody phytoplasmas to periwinkle. J. Phytopathol. 147:187-192.

24. Marcone, C., Ragozzino, A., Credi, R., and Seemüller, E. 1996. Detection and characterization of phytoplasmas infecting grapevine in southern Italy and their genetic relatedness to other grapevine yellows phytoplasmas. Phytopathol. Mediterr. 35:207-213.

25. Marcone, C., Ragozzino, A., and Seemüller, E. 1997. Detection of Bermuda grass white leaf diseases in Italy and characterization of the associated phytoplasma by RFLP analysis. Plant Dis. 81:862-866.

26. McCoy, R. E., Caudwell, A., Chang, C. J., Chen, T. A., Chiykowski, L. N., Cousin, M.-T., Dale, J. L., de Leeuw, G. T. N., Golino, D. A., Hackett, K. J., Kirkpatrick, B. C., Marwitz, R., Petzold, H., Sinha, R. C., Sugiura, M., Whitcomb, R. F., Yang, I. L., Zhu, B. M., and Seemüller, E. 1989. Plant diseases associated with mycoplasma-like organisms. Pages 487-640 in: The Mycoplasmas (Vol. V). R. F. Whitcomb and J. G. Tully, eds. Academic Press, San Diego, CA.

27. Michaux, S., Paillisson, J., Carles-Nurit, M.-J., Bourg, G., Allardet-Servent, A., and Ramuz, M. 1993. Presence of two independent chromosomes in the Brucella melitensis 16M genome. J. Bacteriol. 175:701-705.

28. Mushegian, A. R., and Koonin, E. V. 1996. A minimal gene set for cellular life derived by comparison of complete bacterial genomes. Proc. Natl. Acad. Sci. U.S.A. 93:10268-10273.

29. Neimark, H., and Kirkpatrick, B. C. 1993. Isolation and characterization of full-length chromosomes from non-culturable plant-pathogenic mycoplasma-like organisms. Mol. Microbiol. 7:21-28.

30. Razin, S., Yogev, D., and Naot, Y. 1998. Molecular biology and pathology of mycoplasmas. Microbiol. Mol. Biol. Rev. 62:1094-1156.

31. Schneider, B., Ahrens, U., Kirkpatrick, B. C., and Seemüller, E. 1993. Classification of plant-pathogenic mycoplasma-like organisms using restriction-site analysis of PCR-amplified 16S rDNA. J. Gen. Microbiol. 139:519-527.

32. Schneider, B., Cousin, M.-T., Klinkong, S., and Seemüller, E. 1995. Taxonomic relatedness and phylogenetic positions of phytoplasmas associated with disease of faba bean, sunnhemp, sesame, soybean, and eggplant. Z. Pflanzenkrankh. Pflanzenschutz 102:225-232.

33. Schneider, B., Gibb, K. S., and Seemüller, E. 1997. Sequence and RFLP analysis of the elongation factor Tu gene used in differentiation and classification of phytoplasmas. Microbiology 143:3381-3389.

34. Schneider, B., Marcone, C., Kampmann, M., Ragozzino, A., Lederer, W., Cousin, M.-T., and Seemüller, E. 1997. Characterization and classification of phytoplasmas from wild and cultivated plants by RFLP and sequence analysis of ribosomal DNA. Eur. J. Plant Pathol. 103:675-686.

35. Seemüller, E., Marcone, C., Lauer, U., Ragozzino, A., and Göschl, M. 1998. Current status of molecular classification of the phytoplasmas. J. Plant Pathol. 80:3-26.

36. Seemüller, E., Schneider, B., Mäurer, R., Ahrens, U., Daire, X., Kison, H., Lorenz, K.-H., Firrao, G., Avinent, L., Sears, B. B., and Stackebrandt, E. 1994. Phylogenetic classification of phytopathogenic mollicutes by sequence analysis of $16 \mathrm{~S}$ ribosomal DNA. Int. J. Syst. Bacteriol. 44:440446

37. Smart, C. D., Schneider, B., Blomquist, C. L., Guerra, L. J., Harrison, N. A., Ahrens, U., Lorenz, K.-H., Seemüller, E., and Kirkpatrick, B. C. 1996. Phytoplasma-specific PCR primers based on sequences of the 16S23S rRNA spacer region. Appl. Environ. Microbiol. 62:2988-2993.

38. Suwanto, A., and Kaplan, S. 1989. Physical and genetic mapping of the Rhodobacter sphaeroides 2.4.1 genome: Genome size, fragment identification, and gene localization. J. Bacteriol. 171:5840-5849.

39. Weisburg, W. G., Tully, J. G., Rose, D. L., Petzel, J. P., Oyaizu, H., Yang, D., Mandelco, L., Sechrest, J., Lawrence, T. G., Van Etten, J., Maniloff, J., and Woese, C. R. 1989. A phylogenetic analysis of the mycoplasmas: Basis for their classification. J. Bacteriol. 171:6455-6467.

40. Zreik, L., Carle, P., Bové, J. M., and Garnier, M. 1995. Characterization of the mycoplasmalike organism associated with witches' broom disease of lime and proposition of a Candidatus taxon for the organism, "Candidatus Phytoplasma aurantifolia.” Int. J. Syst. Bacteriol. 45:449-453.

41. Zuerner, R. L., Herrmann, J. L., and Girons, I. S. 1993. Comparison of genetic maps for two Leptospira interrogans serovars provides evidence for two chromosomes and intraspecies heterogeneity. J. Bacteriol. 175: $5445-5451$. 